\title{
Analysis on the Reasons of Learning-weariness Phenomenon for Students in Higher Vocational Colleges and the Countermeasure Research
}

\author{
Yan Xiaoyan, Sun Shu, and Gu Sheng \\ School of Construction Engineering in Taizhou Polytechnic College \\ 225300, Taizhou, Jiangsu
}

\begin{abstract}
Learning-weariness, which refers to the students' negative mind towards study, have7 serious influence on students' future graduation and career, and meanwhile, affect the teachers' sense of achievement to a great extent. This paper studies the reasons generating the learning-weariness psychology of students in higher vocational colleges, which mainly include unhealthy social climate, unscientific school course arrangement, insufficient concern from families and the personal factors of students. With respect to the above mentioned reasons, the school should help students overcome learning-weariness psychology through establishing good environment, intensifying course reform strength, improving teaching level and implementing family-school collaboration supervision and other measures, thus promote their healthy growth, and lay a solid foundation for their future work.
\end{abstract}

Keywords-Learning-weariness; Course reform; Teaching level; Family-school collaboration

\section{INTRODUCTION}

Along with the popularization of higher education, higher vocational education has also entered into a period of fast development. With the input of lots of expenditures and the participation of highly educated teachers and teachers possessing senior engineering background, the school hardware and software facilities are largely improved, but on the contrary, learning-weariness phenomenon is increasingly serious among students in higher vocational colleges. Long with the decrease of student source quantity for participating in college entrance examination, and the expansion of enrollment scale in undergraduate colleges, the student source quality in higher vocational colleges is decreased to some extent, and many students have certain learning barrier; besides, with the influence of online games, etc., they prefer to wasting time in games, films and entertainment projects, but have generate aversion mind towards learning. Learning-weariness is kind of learning barrier and a kind of mental phenomenon, and it generally refers to the expression of students in showing no interest in learning, and generating aversion mind. Generally, the learning-weariness of students can generate a very serious negative influence on students, and firstly, they cannot gain necessary professional knowledge and skills during the academic year, and this has made them fail to adapt to the requirements of work post during the internship period or after graduation, and naturally, they cannot enter into the work status fast, and the employment conditions are increasingly worse many students lose confidence in the later period, and then they are reduced to "boomerang kids", and bring huge harm to families and the society. Moreover, this will further exaggerate the spreading of "learning useless theory", "diploma useless theory" and other bad thoughts, and then result in more and more students paying less attention to learning, and the occurrence of difficult employment, and other phenomena, and then form vicious circle. Secondly, students' learningweariness phenomenon will seriously influence the teaching mind of teachers; teachers carefully prepare lessons, and give lessons, but cannot obtain the due feedback of students, which cannot satisfy the sense of achievement and harvesting sense of teachers, and then eliminate the enthusiasm for teachers to attend class. Besides, with the right-protection awareness of students being strengthened in the recent years, teachers cannot adopt effective means to restrict some behaviors of students, and this can make teachers generate job burnout sense towards teaching, and then cause worse and worse teaching quality, so it is very meaningful to carry out the research about learningweariness phenomenon of students in higher vocational colleges.

Learning-weariness psychology of students can be classified into two types; the first type is distinctive learningweariness, and it refers to the learning-weariness of students in a certain period or towards certain teacher and certain course, and such learning-weariness is generally incurred by external reasons, and can exert a relatively small influence on the growth of students, and this will not be regarded as the main research contents of the article. The other type is the general learning-weariness, i.e., students have passive psychology and resistance behavior status for a long time, and have no imagination about their own specialty, life value, etc. Generally, the learning-weariness phenomenon of students is not simply caused by certain factor, but several factors, and it can be summarized into four points: social factors, school factors, family factors and the personal factors of students. 


\section{ANALYSIS ON THE REASONS OF LEARNING-WEARINESS PSYCHOLOGY FOR COLLEGE STUDENTS}

Social factors; along with the fast development of modernized economy in China, material civilization and spiritual civilization construction have become increasingly unbalanced, which has made the ideological trend violating socialist core values constantly impact the thoughts of modernized college students, such as "learning useless", "marrying well is better than learning well", "graduation equals to unemployment", which are emerging one after another, and have made students give up the opportunity to change their own fate through study and labor, and hope to gain success through reaping without sowing, pulling strings, taking a shortcut and other modes. The spreading of these thoughts has seriously stricken students' learning enthusiasm, and made them lose learning objective, impetus and learning interest, and then generate learning-weariness mind.

School factors; the learning-weariness psychology for most college students is generally started from their middle school period, and they will thoroughly give up their study during college period. Due to the pressure for entering a higher school during middle school period, and most difficult course knowledge, in case of still failing to obtain better performance after making several times of endeavors, some students will gradually lose faith in their own capacity, and directly lose learning motivation. Although many higher vocational colleges input lots of energy and cost in promoting various conditions and environment for the specialty and learning, they neglect the psychological and physiological changes of students during the transient process from senior high schools to colleges. During the college period, students will enter into a relatively relaxed college life from the tense life in high school, and from the family life to half-socialized college life, and the learning contents will be transited from the focus of Chinese, Mathematics and English in senior high schools to various professional courses, and their learning management will be transmitted from arrangement obedience to the selfmanagement of college students. In the face of such huge changes, if students' psychology cannot be timely adjusted, there will be the situation of falling behind course contents, decreasing learning interest, and losing learning objective.

Family factors; through investigation, learning-weariness students in higher vocational colleges can be mainly divided into two types, the first type is "leftover children" from rural areas, these children are separated from their patents during their growth period, and their patents are busy working for life, and don't have more energy and time to educate their children, except for meeting their material life demand as much as possible, so they have to fully entrust their children to schools and social training institutions. They don't pay attention to the formation of students' motivation and learning habit, and almost fully neglect students' psychology, and only judge through scores, without considering students' learning basis, learning interest and other changes, and this has made many students generate pessimistic and give-up psychology during their middle school period. The other type is mainly "little emperor" and "little princess" in cities. Since they live an extravagant life and their elders spoil them, they cannot fully feel the hardship of life, and have no interest in learning, lack in showing respect for knowledge and teachers, and don't have clear objective and plan for their own life.

Personal factors of students; since students are under the special condition of adolescence during middle school and college period, they can be easily influenced by external bad thoughts and phenomena, and can easily generate conformity especially in online games, makeup, dating, quitting school and working part-time, etc. Besides, students have weak selfmanagement capacity, weak willpower and cannot master normal learning method, when encountering with difficulties, students cannot or don't want to study hard, and cannot obtain ideal performance, so their confidence will be undermined, and then they will be caught in online games, and virtual world and cannot get away; they will avoid real life and study, and don't have the mood to study, and this is also the reason causing learning-weariness psychology.

\section{STRATEGIES FOR ALLEVIATING LEARNING-WEARINESS PSYCHOLOGY OF COLLEGE STUDENTS}

In the face of the hazards incurred by learning-weariness phenomenon of students in higher vocational colleges, it is requested to establish good campus learning climate, emphasize on thoughts, psychology and vocational education, reinforce the reform of professional courses, start from familyschool collaboration effect and other aspects, and seek for solutions, to help students get out of learning-weariness dilemma.

\section{A. Establish good school climate, and create a good leaning atmosphere.}

Good campus climate, and correct mainstream awareness can help college students to form correct world view, view of life and value [2]. During daily teaching process and students' daily education management, higher vocational colleges should adopt more active, vivid and effective mode to transmit correct value and view of life to the heart of students, and provide correct direction, healthy contents and "delicious" spiritual food to the healthy physical and mental growth of college students. In the positive environment, students will conscientiously and actively participate in the study, and convert passive learning into active learning [3].

Higher vocational colleges can also organize more rich and colorful campus activities, to decrease the campus network coverage area (even close $4 \mathrm{G}$ wireless network during the teaching area), and then guide the spirits of students from virtual network world to the real life. 


\section{B. Emphasize on thoughts, psychology and vocational} education, and ensure the correct guidance of students.

Currently, higher vocational colleges have set up education type courses such as ideology and politics as well as psychological health during the fresh year, but teachers of such courses are mostly ideological and political teachers, and will mostly adopt the mode of cramming education and pure theory for teaching, without professional pertinence, and this has made students had no interest in such courses, let alone the participation. However, such courses can help students correctly recognize themselves, establish correct value and view of life, and better create life value and serve the society. Thus, such courses must be subject to course reform, and the reform should not only include teaching contents, but also teaching method and means. Adopt the mode of being led by ideological and political teachers taking the lead, with the participation of enterprise tutors and professional teachers, to fully exert the model function of enterprise tutors, and excellent students of the previous periods, and let students find out struggling objective, learning impetus and method in their models. Besides, it is also applicable to adopt the mode of practice-focused and theory supplementation to let students understand the importance of learning and work in their growth through practice. For instance, organizing students to conduct $20 \mathrm{~km}$ cross-country race during the freshmen military training period, to exercise students' willpower, and let them believe that they can succeed step by step, even if the road is difficult. Ideological and political courses can also organize students to do voluntary work at social welfare institutes and other institutions, and let them experience the hardship of life; organize students to participate in campus environment cleaning and other work, and let them appreciate the hard work of their patents. Through several modes of ideological education, it is much better than the effect of simple theoretical education, and it can be more easily accepted by students. Meanwhile, with respect to students for which their jobs cannot match their specialties, organize them to work as interns at their matching units, and let them contact with successful people of the specialty, and let them believe that they can change the their own fate and the fate of their families through making endeavors.

For students with serious learning-weariness problems, it is requested to adopt one-to-one, several-(teachers)-for-one(student) communication mode, to interfere psychological problems and behavior habits of students, and help students recognize themselves, discuss and accept themselves, learn new attitude and behavior mode, and form good, healthy and positive learning habit[4]. Meanwhile, students should combine correct self-cognition and scientific career planning, and then improve their own learning capacity, self-management capacity and social adaptation capacity through several modes, fully dig out their own advantages, overcome their own weakness, and then scientifically plan for their college learning life in combination with their own actual conditions, and realize life objective by stage and steps.

\section{Accelerate course reform strength, and trigger students learning interest}

Due to the lack of sufficient cognition on professional course, and the failure in understanding its application in future work, students can easily lose learning objective and impetus for professional learning. Besides, there are also factors such as the low teaching level of teachers, boring course contents, not flexible enough teaching mode, which are also the main reasons causing the learning-weariness of students. Thus, professional teachers should firstly reinforce course reform strength, actively communicate and cooperate with enterprise engineers, reasonably plan for the objective system of courses, realize the combination of theory and practice, decrease difficult course contents that will not be mostly used in the future work, decrease learning difficulty, or adopt more intuitive and easily accepted mode of students to promote students to study better. Thus, teachers must constantly study professional knowledge, improve learning level and skills, and adopt more advanced teaching method and means to improve the interest of students in courses.

\section{Exert family-school collaboration function, and promote students to form learning habit.}

Parents are the first teacher of children, and they can exert a critical function in their children, and in the face of learningweariness students, it is requested to exert family-school collaboration effect, and parents should exert joint function with the class teacher and instructor, jointly help students build correct learning concept, and master scientific learning method. Meanwhile, it is also requested to encourage students to actively participate in various activities organized by schools, and let them fully play their own interests and hobbies, ensure sufficient sports exercise, and decrease the influence of cell phones, computer games, etc. on them. In the face of the unhealthy phenomenon and wrong concept in the society, parents should timely work together with the class teacher and instructor and help students distinguish what is right and what is wrong, and shouldn't excessively oppress students, or leave their children alone, and it is requested to appropriately help children adjust psychological problems, and timely relieve learning pressure and learning-weariness emotion.

\section{CONCLUSION}

There are more work to do considering the alleviation of students' learning-weariness phenomenon, and as an education worker in higher vocational colleges, we should weigh and handle as per different conditions of students. We should be more patient with students with learning-weariness psychology and be more considerate to them, use education and psychology principle, to stimulate students' internal learning motivation. In case that learning-weariness psychology cannot be eliminated through adopting reasonable mode, expect for seriously influencing students' personal life road, it can also cause fatal influence to the teaching quality and overall development of the school. 


\section{ACKNOWLEDGMENT}

Fund Project: Key Topics for the Higher Education Teaching Reform Research of Jiangsu Province in 2015 (2015JSJG98), Taizhou Polytechnic College Vocational Education Research 2016 Topic (ZY201606, ZY201604)

\section{REFERENCES}

[1] Zhao Ting. Research about the Reasons and Solutions for the Learningweariness Psychology of College Students [J]. Industrial \& Science Tribune, 2016, 23: 262-263.

[2] Chen Xuesong. Preliminary Research about the Learning-weariness Psychology of College Students in Chongqing [D]. Southwest University, 2008.

[3] Han Jun. Research about the Cultivation and Practice of Socialist Core Values in Colleges [D]. Chongqing University of Technology, 2014.

[4] Chen Shaojia. The Current Status of Self-talk for College Students and the Intervention Research about Group Psychology Counseling [D]. Suzhou University, 2013.

[5] Dai Xiaohong. Empirical Research about the Student Analysis of College Students in Higher Vocational Colleges [J]. Heilongjiang Researches on Higher Education, 2014, 01: 115-117.

[6] Cha Yuchi. Brief Analysis about the Learning-weariness Phenomenon and Solutions of Students in Contemporary Higher Vocational Colleges [J]. Contemporary Vocational Education, 2013, 12: 69-71+35.

[7] Tang Feiyun. Reasons and Solutions for Learning-weariness of College Students in construction Type Higher Vocational Colleges [J]. Work \& Study Abroad (Employment Version), 2010, 05: 9-10. 